DOI: https://doi.org/10.32839/2304-5809/2021-3-91-66

УДК $341.1 / 8$

Скрипнік-Горупашенко А.В., Панфілова Ю.М. Київський міжнародний університет

\title{
УЧАСТЬ МІЖНАРОДНИХ ОРГАНІЗАЦІЙ У БОРОТЬБІ 3 МОРСЬКИМ ПІРАТСТВОМ
}

\begin{abstract}
Анотація. Світовий океан відіграє важливу роль для інтересів світової спільноти, що полягає у використанні морів, як арени для міжнародної співпраці в економічній та інших сферах, в розташуванні, в межах морів, окремих елементів інфраструктури держав, в проведенні наукових досліджень, а також у виконанні на морі своїх міжнародних зобов'язань. Нажаль, Світовий океан, використовуеться не тільки на благо людства, на морських просторах не рідко відбуваються акти насильства, зокрема піратські напади, які загрожують безпеці мореплавства. Акти насильства у водах Світового океану посягають на міжнародний та національний правопорядок, на мирну співпрацю держав та міжнародних організацій в різних сферах, на права і свободи людини та інші інтереси держав і їхніх громадян. Зростання кількості протиправних актів, професіоналізм злочинців, ускладнюють протидію з ними. Тому зростає зацікавленість держав та міжнародних організацій у спільній боротьбі з актами насильств та виробленні нових підходів у боротьбі з ними. Тому дана стаття присвячена аналізу сучасних проблем міжнародного співробітництва, за участю міжнародних організацій, в боротьбі з піратством на морі та шляхами їх вирішення. Актуальність цієї проблеми пов'язана з особливою суспільною небезпекою міжнародно-протиправного діяння, що обумовлюе взаємозв'язок морського піратства з іншими міжнародно-протиправними діяннями та його негативним впливом на їх зростання. Зокрема, у статті досліджуеться роль та участь міжнародних організацій у боротьбі з піратством. Висвітлюються проблеми боротьби з даним злочином та заходи, які здійснюе світове співтовариство для безпеки судноплавства. Зазначається, що міжнародні організації діють в інтересах консолідації та координації зусиль міжнародного співтовариства 3 метою стримування та припинення піратства. Визначаеться актуальність проблеми та акцентуеться увага на необхідності вивчення досвіду протидії цьому міжнародному злочину в межах багатонаціонального співробітництва. Пропонуеться подальше вдосконалення діяльності міжнародних організацій в цій галузі, напрямки розвитку міжнародного права і національного законодавства.
\end{abstract}

Ключові слова: піратство, безпека судноплавства, міжнародний злочин, акти насильства, Світовий океан, ООН, НАТО, СС, Міжнародна морська організація, співробітництво держав.

Skrypnik-Horupahenko Anastasia, Panfilova Yulia Kyiv International University

\section{PARTICIPATION OF INTERNATIONAL ORGANIZATIONS IN THE STRUGGLEWITH MARITIME PIRACY}

Summary. The oceans play an important role in the interests of the world community, which is the use of the seas as an arena for international cooperation in economic and other spheres, in the location, within the seas, individual elements of state infrastructure, in research and performance at sea. their international obligations. Unfortunately, the world's oceans are used not only for the benefit of mankind, acts of violence are not uncommon in the seas, including pirate attacks that threaten the safety of navigation. Acts of violence in the waters of the oceans encroach on international and national law and order, on the peaceful cooperation of states and international organizations in various fields, on human rights and freedoms and other interests of states and their citizens. The growing number of illegal acts, the professionalism of criminals, complicates the fight against them. Therefore, the interest of states and international organizations in the joint fight against acts of violence and the development of new approaches to combating them is growing. Therefore, this article is devoted to the analysis of current problems of international cooperation, with the participation of international organizations, in the fight against piracy at sea and ways to solve them. The urgency of this problem is associated with the special social danger of internationally illegal acts, which determines the relationship of maritime piracy with other internationally illegal acts and its negative impact on their growth. In particular, the article examines the role and participation of international organizations in the fight against piracy. The problems of combating this crime and the measures taken by the world community for the safety of navigation are highlighted. It is noted that international organizations are working to consolidate and coordinate the efforts of the international community to deter and stop piracy. The urgency of the problem is determined and emphasis is placed on the need to study the experience of combating this international crime within the framework of multinational cooperation. It is proposed to further improve the activities of international organizations in this area, the direction of development of international law and national legislation.

Keywords: piracy, shipping safety, international crime, acts of violence, World Ocean, UN, NATO, EU, International Maritime Organization, cooperation of states.

$\Pi^{2}$ остановка проблеми. Однією з проблем яка загрожуе міжнародному правопорядку, слід вважати проблему морського піратства. Піратство, маючи міжнародний характер, в даний час, в умовах глобалізацї, як і раніше становить велику загрозу міжнародному судноплавству в багатьох районах Світового океану. Піратство відносять до міжнародних злочинів, його відмінність в тому, що воно відбувається на морі, та перш за все, спрямоване проти безпеки судноплавства. 
У XXI столітті піратство суттево змінилося, набуло нових рис. Протягом багатьох століть піратство існувало з різною інтенсивністю у всіх країнах, які мали вихід до моря. Піратство ніколи не зникало з міжнародної політичної арени. В період його становлення та розвитку відбувалася модифрікація його структури, підвищувалася озброєність піратських центрів, розширювалася сфера впливу, що в подальшому призвело до суттевої перешкоди на шляху до практичної реалізації принщипу свободи судноплавства, завдаючи великої шкоди міжнародній морській торгівлі, суднам, їх пасажирам і членам екіпажів.

Відсутність ефективних механізмів боротьби 3 піратством визначаеться сьогодні, як одна із загроз міжнародній спільноті. Зростаюча взаємозалежність держав у боротьбі з піратством вимагає відповідного відображення в міжнародному праві. Нагальною є потреба активізації міжнародного співробітництва в цій сфері та необхідність більш повного використання можливостей, закладених у нормах міжнародного права. Неефективне використання правових норм, на сьогодні, та низька ефективність механізмів у боротьбі з піратством визначається, як одна із загроз національній безпеці кожної країни та міжнародній спільноті взагалі. Актуальність боротьби з піратством і практика забезпечення міжнародного правопорядку, справедливого судового переслідування, розгляду та винесення судових рішень свідчать про необхідність активізації діяльності міжнародних організацій у боротьбі з цим злочином міжнародного характеру.

Аналіз останніх досліджень та публікацій. Загальні питання, пов'язані з методами боротьби з піратством, міжнародну правову базу боротьби з якими вивчали ряд авторів, зокрема О. Колодкін, Е. Смірнова [7]. Проблеми формування міжнародно-правового механізму протидії піратству висвітлювали в своїх роботах Г. Анцелевич [1], Ю. Панфілова [11], О. Шемякін, В. Прусс [4], М. Будаков [3], Т. Брежнева [2]. Базові правові основи боротьби з піратством були закладені такими міжнародними нормативними документами, як Женевська конвенщія про відкрите море 1958 року, Конвенція ООН з морського права 1982 року, Конвенція ООН про боротьбу з незаконними актами, спрямованими проти безпеки морського судноплавства 1988 року та інші.

Мета статті полягае в тому, щоб дослідити догматичні та доктринальні складові участі міжнародних організацій з таким протиправним явищем, як піратство.

Виклад основного матеріалу. В умовах глобалізації, стрімкого розвитку й розповсюдження інформаційних технологій відбуваеться потужний сплеск піратства. Закордонні й вітчизняні аналітики, прогнозуючи розвиток цього явища, одностайні в тому, що піратство, як загроза національним та колективним інтересам держав, виходить на передній план.

Лідируюче місце у світовій зовнішньоторговельній діяльності належить морським перевезенням. Сьогодні майже 80 відсотків міжнародних комерційних транспортних перевезень здійснюеться морем. Для цього залучено близько 46 тис. суден, 80 тис. портових комплексів світу. Але піратство щорічно завдає шкоди світовій системі морських перевезень на суму близько 30 млрд. доларів [11, с. 146].

В справі співробітництва держав у боротьбі зі злочинністю важливим $е$ співробітництво в рамках міжнародних організацій. I боротьба з таким злочином, як морське піратство не є винятком. Діяльність міжнародних організацій в цій сфеpi має на меті врегулювання питань, пов'язаних 3 безпекою морського судноплавства. I тому міжнародні організації є діевим механізмом консолідації зусиль світової спільноти в сфері боротьби 3 морським піратством.

Зокрема, сьогодні у світі існуе два основних види співробітництва держав у боротьбі з міжнародною злочинністю: укладання міжнародних договорів 3 різних аспектів цієї діяльності та участь держав у міжнародних організаціях, що спеціалізуються на боротьбі зі злочинністю. У міжнародних договорах регулюються питання надання правової допомоги у кримінальних справах, видачі злочинців, передачі засуджених для відбування покарання в країни їх громадянства, захисту прав своїх громадян при кримінальному переслідуванні їх в іншій державі, обміну оперативною та правовою індрормацією, а також проведення спільних профілактичних заходів. Піратство належить до злочинів, переслідування яких регулюеться як законодавством окремих держав, так і міжнародним правом. Це злочин міжнародного характеру, що складається з незаконного захоплення, пограбування або потоплення торгових або цивільних суден, вчинені у відкритому морі. До піратства також прирівнюеться напад під час війни кораблів, підводних човнів і військових літаків на торгові судна нейтральних країн. Піратські судна, літальні апарати і їх екіпажі не повинні користуватися захистом будь-якої держави. Незалежно від прапора піратські судна можуть бути захоплені кораблями або літальними апаратами, що знаходяться на службі будь-якої країни і мають відповідні повноваження [9, с. 231].

За останні роки, коли проблема піратства стала серйозно загрожувати судноплавству, багато держав і міжнародних організацій почали активізацію щодо вирішення цієї проблеми. На даний момент боротьбою 3 піратством активно займаються такі міжнародні структури, як Організація Північноатлантичного договору (НАТО), Рада Безпеки ООН (РБ ООН), Міжнародна морська організація (IMO), Міжнародне морське бюро.

Починаючи з 2008 року НАТО допомагала стримувати та зривати піратські напади, захищаючи судна та допомагаючи підвищити загальний рівень безпеки у Аденській затоці. Наприкінці 2008 року за запитом тодішнього Генерального секретаря ООН Пан Гі Муна НATO розпочала здійснювати супровід суден у рамках операції «Еллайд провайдер», які проходили транзитом крізь ці небезпечні райони та перевозили вантажі у рамках Всесвітньої продовольчої програми ООН. Крім безпосереднього захисту суден, які залучалися до перевезень у рамках цієї програми, НАТО здійснювала патрулювання з метою стримування та, приміром, запобігла захопленню суден та взяттю їхніх екіпажів у заручники під час піратських нападів. Після цього у березні-серпні 2009 року було проведено 
операцію «Еллайд протектор», яка продовжила сприяти безпеці торгових морських шляхів і міжнародного судноплавства. У рамках цієї операції здійснювалося спостереження та продовжували виконуватися завдання, розпочаті під час операції «Еллайд провайдер» [10].

НАТО здійснюе повномасштабні заходи боротьби з піратством у відповідності до резолющій Ради Безпеки ООН. На підтримку резолюцій РБ ООН 1814 [13], 1816 [14] і 1838 [15] сили Альянсу стримували дії піратів в рамках операції «Allied Provider». Кораблі Постійної військово-морської групи НАTO 2 (SNMG2) здійснювали патрулювання вод поблизу узбережжя Сомалі та супровід суден ВПП з продуктами харчування. Постійні військово-морські групи - це багатонаціональні морські сили, які перебувають у стані постійної готовності, як сили швидкого реагування першого ешелону, забезпечують здатність НАТО оперативно реагувати й захищати інтереси Альянсу в будь-якому місці світу. Під час операції до складу Постійної військово-морської групи Сил реагування НАТО 2 входили сім суден з Німеччини, Греції, Італії, Туреччини, Великої Британії та Сполучених Штатів, однак до участі в операції було залучено лише три з них - ITS Durand de la Penne (фрлагман, есмінець D560, Італія); HS Temistokles (фрегат F465, Греція); HMS Cumberland (фрегат F85, Велика Британія), а також TCG Gokova (фррегат F496, Туреччина) [18].

Інші кораблі ціеї групи продовжували розгортання в країнах Стамбульської ініціативи співпраці - Бахрейні, Катарі, Кувейті, ОАЕ. Це було перше розгортання в Перській затоці військово-морських сил під прапором НАТО. Юридично процедура затримання піратського судна кораблями зі складу сил НАТО здійснюеться відповідно до вимог національного законодавства, i будь-яке рішення щодо цього має підлягати його юрисдикції [20]. Тобто будь-які подальші дії стосовно затриманих або наслідки для них визначаються законами і рішеннями ціеї країни. Це стосуеться усіх кораблів, що перебувають під командуванням НАТО, незалежно від їх національної приналежності.

Оцінюючи результати ціеї операції, тодішній Верховний головнокомандувач Об'єднаних збройних сил НАТО в Свропі генерал Д. Креддок підкреслив: «Загроза піратства реальна і зростає сьогодні в багатьох частинах світу, а ця відповідь $€$ наочною ілюстраціею здатності НАТО швидко адаптуватись до нових викликів безпеці» [21]. У результаті обговорення країнами НАТО на політичному рівні можливої довгострокової ролі організації у боротьбі проти піратства, а також заходів з вироблення спільного підходу до затримання піратів, їх міністри оборони під час засідання Південно-Африканських Республік (ПАР) 12 червня 2009 р. вирішили продовжити антипіратську операцію поблизу Африканського рогу і в Аденській затоці [2, с. 15].

Поширення піратства викликало необхідність безпрецедентного розгортання багатонаціональних військово-морських сил під загальним керівництвом Ради Безпеки ООН, на яке надала згоду сомалійська влада. Найбільш вражаючим аспектом реагування Ради Безпеки ООН стало розширення правого режиму відкритого моря на територіальні води Сомалі, що дозволило іноземним фрлотам здійснювати антипіратські заходи у всій зоні. Початковий дозвіл був наданий Резолюцією РБ ООН 1816 від 2 червня 2008 р. на шість місящів та продовжений ще на 12 місяців за резолюцією 1846 від 2 грудня того ж року [23]. Резолюцією 1851 від 16 грудня 2008 р. вводився ще один винятковий захід, що надавав право державам, задіяним у боротьбі з піратством, протягом року, починаючи з 2 грудня 2008 р., «вжити всіх необхідних заходів, доречних у Сомалі», тобто поширював можливості їх втручання на землі цієї країни. При цьому Рада Безпеки ООН була дуже обережна, підкреслюючи винятковий характер ухвалених рішень. Всі резолюції наголошували, що вони не повинні розглядатися, як встановлення нових норм міжнародного права, обмежені в часі й перебувають під ії постійним контролем.

Одним 3 таких важливих документів $є$ Резолюція Ради безпеки ООН № 1816 від 2 червня 2008 року [14], яка започаткувала правові засади для проведення антипіратських операщій в територіальних водах Сомалі, із тим, заклавши міжнародно-правові основи для фрізичного переслідування піратів.

27 квітня 2010 року РБ ООН прийняла резолюцію № 1918 щодо проблеми морського піратства. Резолюція передбачила обов'язок Генерального секретаря ООН зробити у 3-х місячний строк доповідь щодо варіантів судового переслідування осіб, підозрюваних у піратстві [16]. 25 липня 2010 року Генеральний секретар ООН презентував свою доповідь на засіданні РБ ООН, в якій запропоновано 7 варіантів створення чи використання вже наявних судових установ для переслідування морських піратів: 1) збільшення допомоги ООН з метою зміцнення потенціалу держав у регіоні для судового переслідування та ув'язнення осіб, які є відповідальними за акти піратства та збройного пограбування на морі біля узбережжя Сомалі; 2) створення сомалійського судового органу, який проводитиме засідання на території будь-якої третьої держави в регіоні за або без участі ОOH; 3) створення спеціальної палати в рамках нащіональної судової системи однієї чи кількох держав регіону без участі ООН; 4) створення спеціальної палати в рамках національної судової системи однієї чи кількох держав регіону з участю ООН; 5) створення регіонального трибуналу на основі багатосторонньої угоди між державами регіону за участі ООН; 6) створення міжнародного трибуналу на основі угоди між державою регіону та $\mathrm{OOH}$; 7) створення міжнародного трибуналу шляхом резолюції Ради безпеки $\mathrm{OOH}$ на підставі глави VII Статуту ОOH [5].

Міжнародне співробітництво в боротьбі 3 піратством грунтуеться на Конвенція ООН з морського права (10 грудня 1982 р.) ратифікована Україною згідно із Законом від 03.06.1999 р. № 1728-ХТУ [12], як на загальному документі, який регулює міжнародне використання морських просторів, а також на спеціальних міжнародних договорах, серед яких найважливішим $є$ Конвенція про боротьбу з незаконними актами, спрямованими проти безпеки морського судноплавства 1988 р. (набула чинності для України 
20 липня 1994 р.) [8]. Саме ця Конвенція визначає загальні риси складів злочинів, які підлягають уніфікації в національному законодавстві.

Міжнародно-правові норми про піратство спочатку виникали та розвивалися як звичаєво-правові. Особлива небезпека піратства в тому, що воно перетворюється на промисел міжнародних злочинних організацій. Пропозиції 3 кодифікації норм про злочинність піратства та боротьби 3 ним виникали на початку XIX ст., але реалізовані були значно пізніше - у Конвенції про відкрите море 1958 р. [6]. і в Конвенції з морського права $1982 \mathrm{p}$.

У боротьбі з піратством зростае значення співробітництва держав, яке здійснюеться в рамках міжнародних міжурядових організацій, таких як Міжнародна морська організація, яка є спеціалізованою установою ООН. У 2004 році організацією був прийнятий міжнародно-правовий акт, який регулюе окремі питання попередження актів піратства - Міжнародний кодекс 3 охорони суден та портових споруд. Кодекс встановлює уніфріковані стандарти безпеки, у тому числі щодо несанкціонованого проникнення сторонніх осіб на судно. Міжнародна морська організація неодноразово приймала циркуляри для держав-членів ціеї організації з питань піратства (Циркуляр Комітету по безпеці мореплавства ММО від 22.06.1993 р. № 662 «піратство та розбій по відношенню до суден») [19]. Тією ж організацією були розроблені декілька рекомендацій з метою боротьби з піратством та пограбуваннями суден. Однак зміст цих рекомендацій мало в чому може практично допомогти морякам у боротьбі зі злочинцями. Адже використання водяних струменів пожежних шлангів суден, забезпечення посилених вахт за надводною обстановкою та маневрування 3 метою запобігання проникнення піратів на борт судна не $є$ едрективними засобами проти озброєних вогнепальною зброєю, володіючих високошвидкісними катерами піратів. Це змушуе моряків застосовувати власні, інколи не зовсім законні заходи попередження піратських атак. Наприклад, використання у небезпечних 3 точки зору піратства районах Світового океану прийомів світломаскування, відомих ще 3 часів світових воєн, коли в темну частину доби на судні виключались навіть навігаційні вогні з тим, щоб пірати не змогли помітити судно. Морякам відомо, наскільки це небезпечно в районах інтенсивного судноплавства і такі дії є прямим порушенням Міжнародних правил попередження зіткнень суден в морі 1972 року, однак це те зло, яке $є$ меншим.

У багатьох країнах почали усвідомлювати, що боротьба зі злочинністю на морі, зважаючи на їі специфічність і складність, не може бути прерогативою окремого державного органу або держави, головну координуючу роль у цьому процесі відіграє IMO й особливо її Комітет з безпеки на морі - КБМ [17, с. 12].

У листопаді 2001 р. на 22-йсесії Асамблеї IMO було одноголосно прийнято Резолюцію А.924(22), що констатувала необхідність вироблення нових заходів стосовно захисту суден. У грудні 2002 р. на II конференщї держав-учасниць СОЛАС-74 було прийнято низку нових рішень щодо посилення безпеки на морі як доповнень до СОЛАС-74. Зокрема, був ухвалений Міжнародний кодекс 3 охо- рони суден та портових засобів (Кодекс ОСПЗ), який набув чинності з 1 липня 2004 року.

Важливу роль у координащії зусиль міжнародного морського співтовариства в питаннях боротьби з піратством відіграє Міжнародне морське бюро (IMB), а також Центр інформації про піратство IMB, відкритий у 1992 р. в малайзійському місті Куала-Лумпур, який відстежуе інформацію про піратів і їх напади на судна, сприяє розслідуванню цих злочинів [1, с. 322].

За статистичними даними начальника штабу EUNAVFOR (угруповання кораблів BMC країн СC) капітана 1 рангу Філіпа Хеслема, у середньому збитки від піратства складають близько 7-12 млрд. доларів за рік. Середня сума викупу великого судна - близько 4,5 млн. доларів.

Невтішною є статистика і для України, оскільки десятки тисяч українських екіпажів ходять на кораблях під прапорами різних держав світу. Тільки за останні роки були захоплені десятки суден з українськими моряками. Серед найбільш резонансних захоплень - судна "Фаїна» (з вантажем зброї), "Аріана», «Леманн Тімбер», «Lugela» та «Beluga Fortune». Власне для України проблема морського піратства масштабно постала у 2005 році із захопленням судна "Panagia» 3 повністю українським екіпажем. Спеціальна група співробітників Апарату Ради національної безпеки і оборони України, яка займалася визволенням судна і до складу якої входив автор ціеї статті, стикнулася з значною кількістю проблем, основні з яких знаходилися в площині недосконалості міжнародно-правових норм та взаємодії спеціальних служб і правоохоронних органів іноземних держав [3, с. 74].

Акти піратства перешкоджають торговельним інтересам країн, що перебувають в зоні діяльності піратів. До таких країн належать: Бенін, Того, Кот-Д'Івуар, Гана, Нігерія і Демократична Республіка Конго. Приміром, обсяги торгівлі головного порту Беніну впали на 70\%. Збитки від діяльності піратів у Гвінейській затоці складають близько 2 млрд. доларів США.

Слід зазначити, що на сьогодні рівень морського піратства у світі став найнижчим за останні роки. Про це йдеться в опублікованій у столиці Малайзіі Куала-Лумпурі доповіді регіонального відділення Міжнародного морського бюро. «Найвагоміша причина зменшення рівня піратства по всьому світу - це зниження сомалійського піратства біля берегів Східної Афррики» - йдеться у заяві директора Міжнародного морського бюро Поттенгала Макундана [5]. За його словами зменшити активність піратів допомогли озброєні охоронці на суднах, міжнародне патрулювання, а також «стабілізуючий вплив» уряду Сомалі.

Висновки. Вищезазначене дозволяе нам стверджувати що існує реальна небезпека для морського судноплавства й для права кожної людини на життя, яку не можна замовчувати. Заходи, вжиті світовим співтовариством і міжнародними організаціями в сорері протидії піратству, є досить ефективними, але проблема піратства залишається однією 3 найактуальніших, що значно впливає на торгове судноплавство в певних регіонах Світового океану і навіть - на стан регіональної безпеки. Успішна протидія та боротьба з піратством в сучасних умов не можлива без координащії зусиль міжнародного співтовариства 
та розвитку регіонального співробітництва. Найбільш давні проблеми людства нині постають з новими загрозами при всій їх екзотичності та виявляються найбільш живучими. Дана обставина, однак, скоріше свідчить лише про необхідність вжиття кардинальних заходів і виділення великих ресурсів 3 розробкою довгострокової програми. Тим більше, що спільні зусилля держав i міжнародних організацій, як показує практика, здатні вплинути на стан справ у даній сфрері.

\section{Список літератури:}

1. Анцелевич Г. О., Покрещук О. О. Міжнародне право : підручник. Київ : Алерта, 2003. 410 с.

2. Брежнева Т. В. Операції проти піратів: шлях до нової морської стратегії НАТО. Наукові праці Чорнолорського державного університету імені Петра Могили. Серія : Політологія. 2011. Т. 155. Вип. 143. С. 14-22.

3. Будаков М. О. Актуальні питання боротьби з морським піратством. Боротьба з організованою злочинністю та корупцією (теорія і практика). 2006. № 13. С. 73-80.

4. Демиденко В. В., Прусс В. М., Шемякин А. Н. Пиратство, терроризм, мошенничество на море. Правовые аспекты : монография. Одесса : Бахва, 1997. 143 с.

5. Доклад Генерального секретаря о возможных вариантах содействия достижению цели судебного преследования и заключении в тюрьму лиц, ответственных за акты пиратства и вооруженного разбоя на море у побережья Сомали. URL: http://www.un.org/ga/ (дата звернення: 01.02.2021).

6. Женевська конвенція про відкрите море 1958 p. URL: http://zakon1.rada.gov.ua/cgi-bin/laws/main.cgi? nreg=995_180. (дата звернення: 05.02.2021).

7. Колодкин А. Л., Смирнова Е. С. Правовое регулирование борьбы с морским пиратством на международном и национальном уровнях: состояние и перспектива в начале XXI века. Государство и право. Москва, 2013. № 11. C. $123-124$.

8. Конвенщія про боротьбу з незаконними актами, спрямованими проти безпеки морського судноплавства 1988 p. URL: http://zakon1.rada.gov.ua/cgi-bin/laws/main.cgi?nreg=995_074 (дата звернення: 03.02.2021).

9. Мишко А. Міжнародні організації у боротьбі з піратством. Міжнародний науковий вісник. Випуск 1-2 (19-20). Ужгород, 2019. С. 230-244.

10. Організація північноатлантичного договору. Операції з боротьби з піратством від 11 травня 2011 р. URL: http://www.nato.int/cps/uk/natohq/topics_48815.htm (дата звернення: 03.02.2021).

11. Панфілова Ю. М. Міжнародно-правове регулювання в сфері протидії проявам піратства та морського тероризму. Зовнішня торгівлі: еконоліка, фбінанси, право. Київ : УДУФМТ, 2012. № 6(65). С. $146-151$.

12. Про ратифікацію Конвенції Організації Об'еднаних Націй з морського права 1982 року та Угоди про імплементацію Частини XI Конвенції Організації Об'еднаних Націй з морського права 1982 року : Закон України від 3 червня 1999 р. № 728-XIV. Відолості Верховної Ради України. 1999. № 31. Ст. 254.

13. Резолюція Ради Безпеки ООН №1814 (2008). Положення в Сомалі. URL: http://zakon4.rada.gov.ua/laws/ show/995_h04 (дата звернення: 01.02.2021).

14. Резолюція Ради Безпеки OOH №1816 (2008). Положення в Сомалі. URL: http://www.un.org/russian/documen/ scresol/res2008/res1816.htm (дата звернення: 03.02.2021).

15. Резолюція Ради Безпеки ООН № 1839 (2008). URL: http://zakon4.rada.gov.ua/laws/show/995_h42 (дата звернення: 03.02.2021).

16. Резолюція Ради Безпеки ООН №1918 (2010). Положення в Сомалі. URL: http://daccess-dds-ny.un.org/doc/ (дата звернення: 03.02.2021).

17. Савельев Н. В. Международное морское сообщество объединяет усилия в борьбе с преступностью на море. Морские вести России. 2008. № 9-10. C. 12-13.

18. Counter-piracy operations. URL: http://www.nato.int/cps/en/natolive/topics_48815.htm (дата звернення: 05.02.2021).

19. Piracy off Somalia high on the agenda as IMO Maritime Safety Committee meets. URL: http://www.imo.org/ (дата звернення: 04.02.2021).

20. Scheffler A. Piracy - threat or nuisance? Research Paper. Research Division. NATO Defense College. Rome. 2010.

21. Standing NATO Maritime Group transits Suez Canal en-route to anti-piracy duties. URL: http://www.nato.int/ cps/uk/natolive/news_46388.htm (дата звернення: 05.02.2021).

22. The situation in Somalia. Resolution 1846 (2008) Adopted by the Security Council at its 6026th meeting, on 2 December 2008. URL: http://daccessods.un.org/TMP/2731059.html (дата звернення: 03.02.2021).

23. The situation in Somalia. Resolution 1851 (2008) Adopted by the Security Council at its 6046th meeting, on 16 December 2008. URL: http://daccessods.un.org/TMP/8992822.html (дата звернення: 05.02.2021).

\section{References:}

1. Antselevych H. O., Pokreshchuk O. O. (2003) Mizhnarodne pravo [International Law]. Kyiv: Alerta.

2. Brezhnieva T. V. (2011) Operatsii proty pirativ: shliakh do novoi morskoi stratehii NATO [Operations against pirates: the path to a new NATO naval strategy] Scientific works of the Black Sea State University named after Petro Mohyla, vol. 143, pp. 14-22.

3. Budakov M. O. (2006) Aktualni pytannia borotby z morskym piratstvom [Current issues in the fight against maritime piracy]. Fight against organized crime and corruption (theory and practice), vol. 13, pp. 73-80.

4. Demidenko V. V., Pruss V. M., Shemyakin A. N. (1997) Piratstvo, terrorizm, moshennichestvo na more. Pravovyie aspektyi: monografiya [Piracy, terrorism, sea fraud. Legal aspects: monograph]. Odessa: Bahva.

5. Doklad Generalnogo sekretarya o vozmozhnyih variantah sodeystviya dostizheniyu tseli sudebnogo presledovaniya i zaklyuchenii v tyurmu lits, otvetstvennyih za aktyi piratstva i vooruzhennogo razboya na more u poberezhya Somali [Report of the Secretary-General on options to help achieve the goal of prosecuting and imprisoning those responsible for acts of piracy and armed robbery at sea off the coast of Somalia]. Available at: http://www.un.org/ga/ (accessed 1 February 2021).

6. Zhenevska konventsiia pro vidkryte more [Geneva Convention on the High Seas] (1958). Available at: https://zakon.rada.gov.ua/cgi-bin/laws/main.cgi?nreg=995_180 (accessed 5 February 2021).

7. Kolodkin A. L., Smirnova E. S. (2013) Pravovoe regulirovanie borbyi s morskim piratstvom na mezhdunarodnom i natsionalnom urovnyah: sostoyanie i perspektiva v nachale XXI veka [Legal regulation of the fight against sea piracy at the international and national levels: state and perspective at the beginning of the XXI century]. State and law, no. 11, pp. 123-124. 
8. Konventsiia pro borotbu z nezakonnymy aktamy, spriamovanymy proty bezpeky morskoho sudnoplavstva [Convention for the Suppression of Unlawful Acts against the Safety of Maritime Navigation] (1988). Available at: http://zakon1.rada.gov.ua/cgi-bin/laws/main.cgi?nreg=995_074 (accessed 3 February 2021).

9. Myshko A. (2019) Mizhnarodni orhanizatsii u borotbi z piratstvom [International organizations in the fight against piracy]. International scientific bulletin, vol. 1-2 (19-20), pp. 230-244.

10. Orhanizatsiia pivnichnoatlantychnoho dohovoru. Operatsii z borotby z piratstvom vid 11 travnia 2011 [Organization of the North Atlantic Treaty. Anti-piracy operations of 11 May 2011]. Available at: http://www.nato.int/cps/uk/ natohq/topics_48815.htm (accessed 3 February 2021).

11. Panfilova Yu. M. (2012) Mizhnarodno-pravove rehuliuvannia v sferi protydii proiavam piratstva ta morskoho teroryzmu [International legal regulation in the field of combating piracy and maritime terrorism]. Foreign trade: economics, finance, law, no. 6(65), pp. 146-151.

12. Pro ratyfikatsiiu Konventsii Orhanizatsii Obiednanykh Natsii z morskoho prava 1982 roku ta Uhody pro implementatsiiu Chastyny XI Konventsii Orhanizatsii Obiednanykh Natsii z morskoho prava 1982 roku: Zakon Ukrainy vid 3 chervnia 1999 r. № 728-XIV. Vidomosti Verkhovnoi Rady Ukrainy [Information of the Verkhovna Rada of Ukraine], no. 31, art. 254.

13. Rezoliutsiia Rady Bezpeky OON №1814 (2008). Polozhennia v Somali [UN Security Council Resolution 1814 (2008). Situation in Somalia]. Available at: http://zakon4.rada.gov.ua/laws/show/995_h42 (accessed 1 February 2021).

14. Rezoliutsiia Rady Bezpeky OON №1816 (2008). Polozhennia v Somali [UN Security Council Resolution 1816 (2008). Situation in Somalia]. Available at: http://www.un.org/russian/documen/scresol/res2008/res1816.htm (accessed 3 February 2021).

15. Rezoliutsiia Rady Bezpeky OON № 1839 (2008) [UN Security Council Resolution №1839 (2008)]. Available at: http://zakon4.rada.gov.ua/laws/show/995_h42 (accessed 1 February 2021).

16. Rezoliutsiia Rady Bezpeky OON № 1918 (2010). Polozhennia v Somali [UN Security Council Resolution №1918 (2010). Situation in Somalia]. Available at: http://daccess-dds-ny.un.org/doc/ (accessed 3 February 2021).

17. Savelev N. V. (2008) Mezhdunarodnoe morskoe soobschestvo ob'edinyaet usiliya v borbe s prestupnostyu na more [The international maritime community joins forces to fight crime at sea]. Maritime news of Russia, no. 9-10, pp. 12-13.

18. Counter-piracy operations. Available at: http://www.nato.int/cps/en/natolive/topics_48815.htm (accessed 5 February 2021).

19. Piracy off Somalia high on the agenda as IMO Maritime Safety Committee meets. Available at: http://www.imo.org/ (accessed 4 February 2021).

20. Scheffler A. Piracy - threat or nuisance? Research Paper. Research Division. NATO Defense College. Rome. 2010.

21. Standing NATO Maritime Group transits Suez Canal en-route to anti-piracy duties. Available at: http://www.nato.int/ cps/uk/natolive/news_46388.htm (accessed 5 February 2021).

22. The situation in Somalia. Resolution 1846 (2008) Adopted by the Security Council at its 6026th meeting, on 2 December 2008. Available at: http://daccessods.un.org/TMP/2731059.html (accessed 3 February 2021).

23. The situation in Somalia. Resolution 1851 (2008) Adopted by the Security Council at its 6046th meeting, on 16 December 2008. Available at: http://daccessods.un.org/TMP/8992822.html (accessed 5 February 2021). 